\title{
Periodontal Application of Manuka Honey: Antimicrobial and Demineralising Effects In Vitro
}

\author{
Syarida H. Safii, ${ }^{1,2}$ Geoffrey R. Tompkins, ${ }^{1}$ and Warwick J. Duncan' \\ ${ }^{1}$ Sir John Walsh Research Institute, Faculty of Dentistry, University of Otago, Dunedin 9016, New Zealand \\ ${ }^{2}$ Department of Restorative Dentistry, Faculty of Dentistry, University of Malaya, 50603 Kuala Lumpur, Malaysia \\ Correspondence should be addressed to Warwick J. Duncan; warwick.duncan@otago.ac.nz
}

Received 10 December 2016; Revised 27 February 2017; Accepted 28 February 2017; Published 14 March 2017

Academic Editor: Timo Sorsa

Copyright (c) 2017 Syarida H. Safii et al. This is an open access article distributed under the Creative Commons Attribution License, which permits unrestricted use, distribution, and reproduction in any medium, provided the original work is properly cited.

\begin{abstract}
Background. Topical application of manuka honey is effective in the treatment of burns and soft-tissue infections. The aim of this study was to assess the antibacterial activity of manuka honey against plaque-associated bacteria in vitro in order to evaluate the potential application as an adjunct to periodontal treatment. Materials and Methods. The minimum bacteriostatic and bactericidal concentrations (MIC and MBC) of manuka honey were compared to those of white clover honey against a variety of plaque-associated bacteria, at the natural and neutral $\mathrm{pH}$. Dissolved calcium was measured following incubation of honeys with hydroxyapatite (HA) beads to assess their potential to demineralise oral hard tissues. Results. Both honeys inhibited most tested oral bacteria at similar MIC/MBC, but Streptococcus mutans was comparatively resistant. The honeys at $\mathrm{pH}$ neutral had little effect on antimicrobial activity. Incubation of HA beads in honey solutions resulted in $\mathrm{pH}$-dependent calcium dissolution, and inoculation with S. mutans promoted further demineralisation by both types of honey. Conclusion. Manuka honey is antimicrobial towards representative oral bacteria. However, the relative resistance of $S$. mutans in association with the high concentrations of fermentable carbohydrates in honey and the direct demineralising effect at natural $\mathrm{pH}$ mitigate against the application of honey as an adjunct in the treatment of periodontal disease.
\end{abstract}

\section{Introduction}

Honey has been used since ancient times in many cultures to treat infections and other medical conditions $[1,2]$. Since the 1990s, research on honeys has regained momentum, with focus towards antibacterial properties particularly against bacteria associated with antibiotic-resistance and infected wounds [3-5]. This has led to approval for use of manuka honey in the treatment of infected wounds, burns, and ulcers [6-9]. Furthermore, with increasing bacterial resistance to antimicrobials used in periodontal therapy $[10,11]$, there is a requirement to explore alternatives to conventional antibiotics.

The antibacterial factors in honey include the hyperosmolarity effect ( $>80 \%$ sugar content), acidic $\mathrm{pH}$, hydrogen peroxide, methylglyoxal, bee defensin-1, various proteinaceous compounds, flavonoids, and phenolic compounds $[4,12,13]$, but the principal antimicrobial activity of most honeys is due to hydrogen peroxide [14]. Medical-grade manuka honey, derived from the shrub Leptospermum scoparium (native to New Zealand and Australia), contains unusually high concentrations of methylglyoxal and only trace amounts of hydrogen peroxide $[12,13,15]$.

Nonperoxide antibacterial activity (NPA) (commercially registered as Unique Manuka Factor $\left[\mathrm{UMF}^{\circledR}\right]$ ) indicates the antibacterial efficacy against Staphylococcus aureus, expressed as the equivalent phenol concentration [16]. The antimicrobial activity of honeys varies depending on botanical, geographical, and seasonal conditions. In New Zealand, manuka honey with elevated antimicrobial activity is harvested from select regions in the North Island, particularly East Cape, Waikato, and Bay of Plenty [17].

Manuka honey has antimicrobial activity in vitro towards a variety of bacteria including dental plaque-associated bacteria, both as planktonic and biofilm organisms [18-20]. Porphyromonas gingivalis, which is associated with various periodontal diseases [21], and Aggregatibacter actinomycetemcomitans, associated with aggressive periodontitis [22], are 
sensitive to manuka honey when grown as planktonic bacteria $[23,24]$ but $P$. gingivalis is considerably more resistant when cultivated as a biofilm [25]. English et al. [26] reported reduced plaque accumulation and gingival bleeding among human participants with gingivitis after chewing manuka honey strips for ten minutes daily for 21 days, suggesting beneficial application of manuka honey as an oral health aid.

The aim of this study was to assess the antibacterial activity of medical-grade manuka honey in vitro against dental plaque-associated bacteria. Manuka honey has a $\mathrm{pH}<$ 4 and is principally composed of fermentable carbohydrate which may mitigate against direct application adjacent to mineralised oral tissues. Thus, to explore the potential of manuka honey as a locally delivered subgingival clinical adjunct in the treatment of chronic periodontitis, we also evaluated the demineralising potential of honey.

\section{Materials and Methods}

2.1. Bacterial Strains and Culture Conditions. Staphylococcus aureus Oxford, Escherichia coli $\mathrm{DH} 5 \alpha$, Streptococcus mutans UA159, Streptococcus mutans ATCC 10449, Streptococcus sobrinus OMZ 176, Streptococcus sanguinis ATCC 10556, Streptococcus gordonii ATCC 10558, Fusobacterium nucleatum ATCC: 10953, 25586, 33568, 49256; Porphyromonas gingivalis ATCC 33277, and Prevotella intermedia ATCC 25611 were from the University of Otago culture collection. Staph. aureus and E. coli were included as reference gram-positive and gram-negative bacteria, respectively $[27,28]$.

Staph. aureus and E. coli were cultured in tryptic soy broth (TSB) (BactoTM, Becton Dickinson Co., Sparks, MD, USA) and on TSB agar, under aerobic conditions. Streptococci were cultured on Columbia sheep-blood agar (CBA) (Fort Richard, Mt. Wellington, New Zealand) under anaerobic conditions $\left(10 \% \mathrm{H}_{2}, 5 \% \mathrm{CO}_{2}\right.$, and $\left.85 \% \mathrm{~N}_{2}\right)$ in a MACS work station (MG500, Don Whitley Scientific Ltd., Shipley, United Kingdom) and were grown in brain heart infusion (BHI) (Difco Laboratories, Detroit, MI, USA). F. nucleatum, $P$. gingivalis, and $P$. intermedia were cultured and maintained under anaerobic conditions on CBA and in prereduced BHI supplemented with hemin chloride $(5 \mu \mathrm{g} / \mathrm{ml}$; Sigma Chemical Co., St. Louis, MO, USA) and menadione $(1 \mu \mathrm{g} / \mathrm{ml}$; Sigma). All incubations were at $37^{\circ} \mathrm{C}$.

2.2. Honey Preparations. Medical-grade manuka honey (NPA20+ and NPA25+, Comvita New Zealand Ltd., Bay of Plenty, New Zealand) and nonmedical grade white clover honey (Hollands NZ Honey Ltd., Timaru, New Zealand) were purchased from local retailers. Each honey was dissolved in culture medium to $50 \%(\mathrm{w} / \mathrm{v})$, filter-sterilised $(0.22 \mu \mathrm{m}$; Millex ${ }^{\circledR} \mathrm{GP}$, Merck Millipore Ltd., Carrigtwohill, Ireland), and further diluted in sterile medium. Honey/culture medium preparations were adjusted to $\mathrm{pH} 7.1( \pm 0.05)$ by adding calcium hydroxide (Sigma Aldrich, St. Louis, MO, USA) using a microprocessor $\mathrm{pH}$ meter ( $\mathrm{pH} 211$ with HI 1230B electrode, Hanna Instruments, Woonsocket, RI, USA). The $\mathrm{pH}$-adjusted honey preparations were filter-sterilised and diluted in culture media.
2.3. Bacteriostatic and Bactericidal Assays. Minimum inhibitory concentration (MIC) and minimum bactericidal concentration (MBC) assays were performed according to CLSI reference methods for bacteria [29]. Assays were prepared in 96-well flat-bottomed microtitre trays, each well containing $200 \mu \mathrm{L}$ of honey preparation inoculated with $10 \mu \mathrm{L}$ of bacterial culture adjusted to a McFarland standard of 0.5 . The MICs were determined by optical density $\left(A_{600}\right)$ measurement (Biotek Instruments Synergy 2, Vermont, NE, USA) and MBCs by spot-plating $10 \mu \mathrm{L}$ onto appropriate agar followed by incubation (as above). MBC was determined as the lowest concentration resulting in complete killing of the test bacterium. The MBC assay was adapted to determine the rapidity of killing by removing and plating samples at specific times.

2.4. Demineralisation Assay. The honeys were dissolved in distilled water at $50 \%(\mathrm{w} / \mathrm{v})$, and $1 \mathrm{~mL}$ was added to $10 \mathrm{mg}$ of hydroxyapatite (HA) beads (particle size of $80 \mu \mathrm{m}$; BioRad Laboratories, Hercules, CA, USA). Hydrochloric acid $(0.1 \mathrm{M})$ and distilled water were used as positive and negative demineralisation controls, respectively. After incubation for $24 \mathrm{~h}$, supernatants were recovered and solubilised calcium measured with a colorimetric detection assay kit (Abcam Australia Pty Ltd., Melbourne, Australia) according to the manufacturer's directions. Honey preparations (without HA beads) were assayed to determine intrinsic calcium concentrations which were subtracted from the demineralisation assays.

The demineralisation assay was modified to assess the additional influence of $S$. mutans. Honey dilutions were prepared in TSB without dextrose (TSB w/o D; Difco) and $1 \mathrm{~mL}$ was added to each tube containing sterilised HA beads (10 mg). An aliquot $(50 \mu \mathrm{L})$ of $S$. mutans (grown for $18 \mathrm{~h}$ in TSB w/o D) was used to inoculate the honey/HA preparations which were incubated for 24 hours. Supernatant samples were analysed for solubilised calcium.

\section{Results}

3.1. Bacteriostatic and Bactericidal Activities of Honeys. Neither manuka nor clover honey exhibited antibacterial effects within four-hour exposure to bacteria. With the exception of $S$. mutans, all tested bacteria were inhibited by both types of honey after $18 \mathrm{~h}$ incubation (Figure 1). Manuka honey displayed slightly greater inhibitory efficacy, with MICs ranging between $6.3 \%$ and $25 \%$, whereas the MICs of clover honey ranged from $6.3 \%$ to $50 \%$ (Figure 1). Manuka honey was slightly more acidic than clover honey (Figure 1).

The MBCs of manuka honey showed a range of between $12.5 \%$ and $50 \%(\mathrm{w} / \mathrm{v})$ and clover honey from $6.3 \%$ to $50 \%$ (Table 1; Figure 2). S. mutans was the most resistant of the tested species against both types of honey (Table 1) but was killed by manuka honey (NPA25+) at 50\% (Figure 2). The bactericidal activity of both types of honey required $18 \mathrm{~h}$ exposure (Table 1; Figure 2). Following adjustment of the $\mathrm{pH}$ to neutrality, the bactericidal activity of manuka honey was largely maintained (Table 1; Figure 2(a)) whereas 


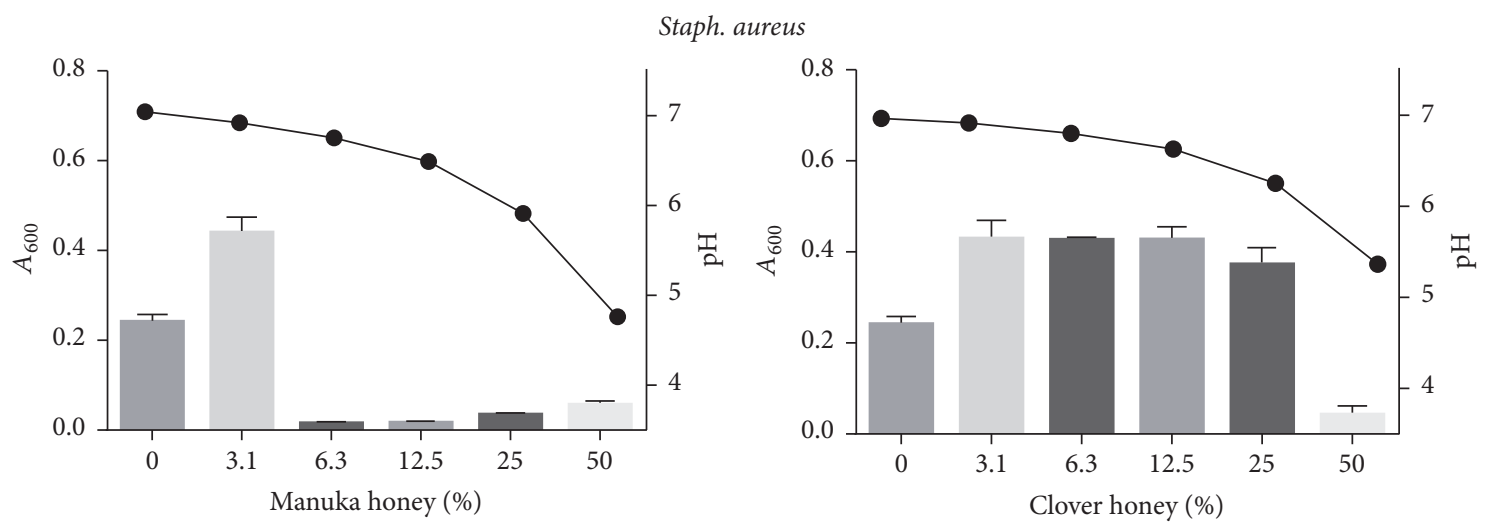

(a)

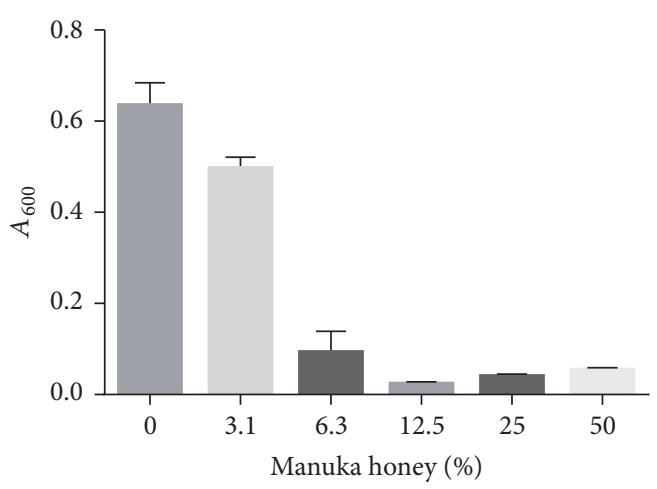

E. coli

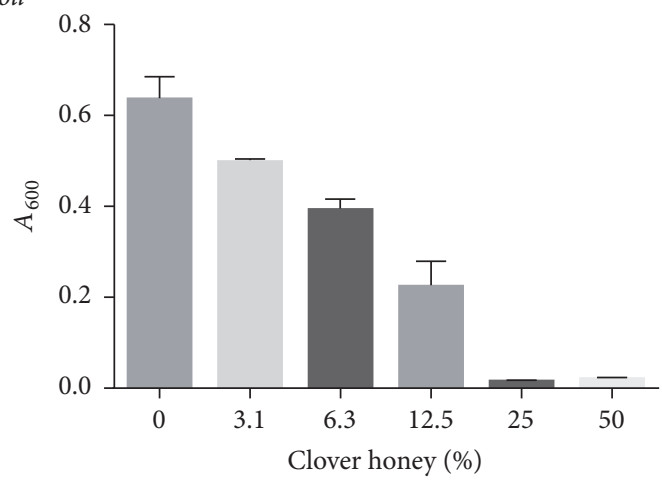

(b)

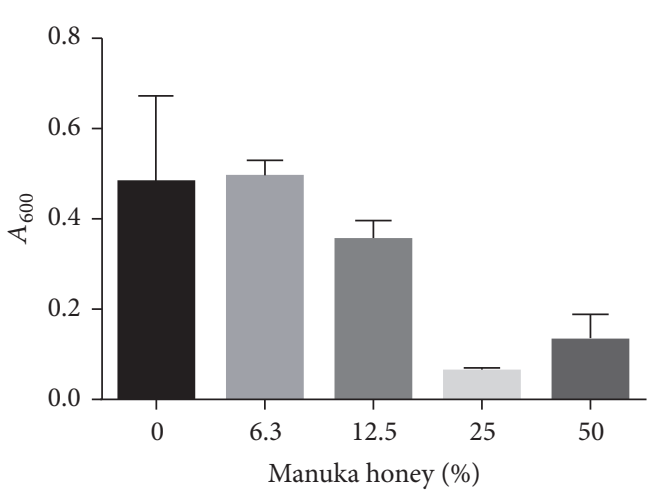

S. mutans

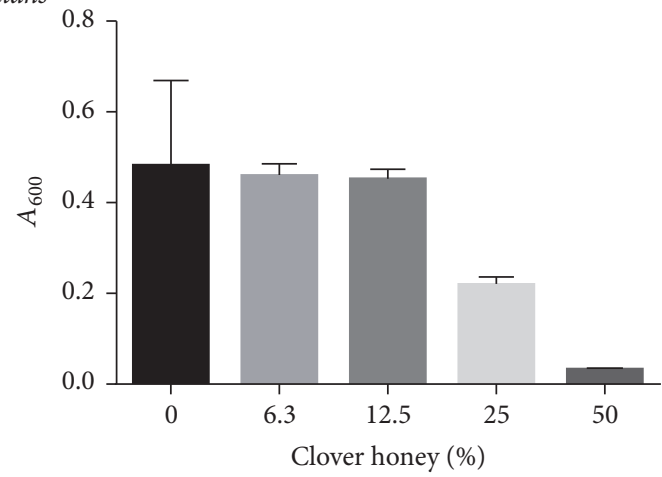

(c)

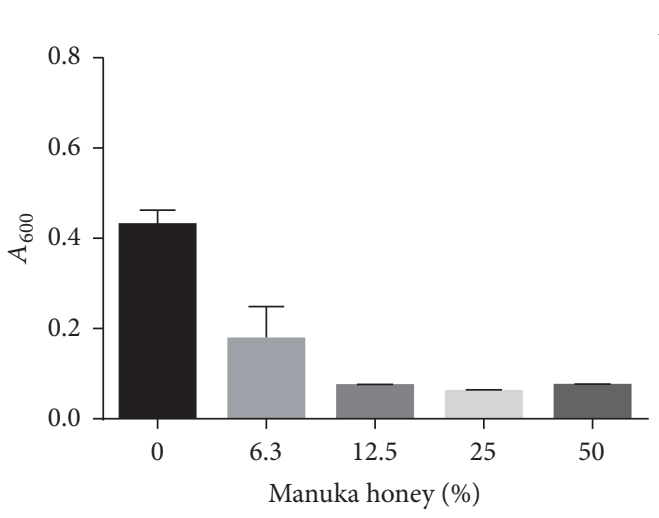

F. nucleatum

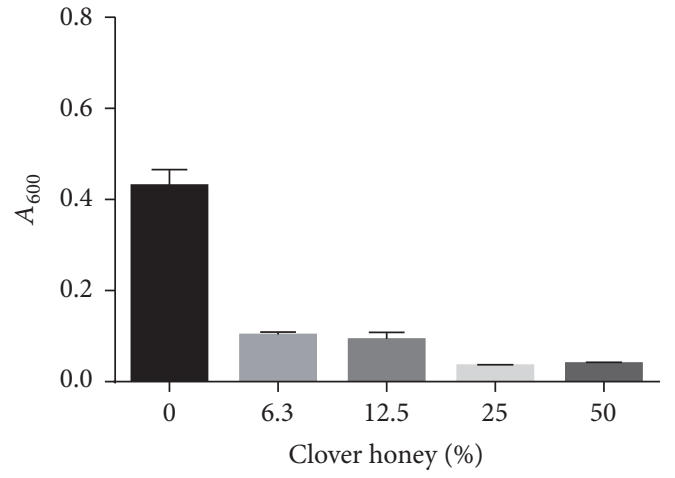

(d)

Figure 1: Continued. 

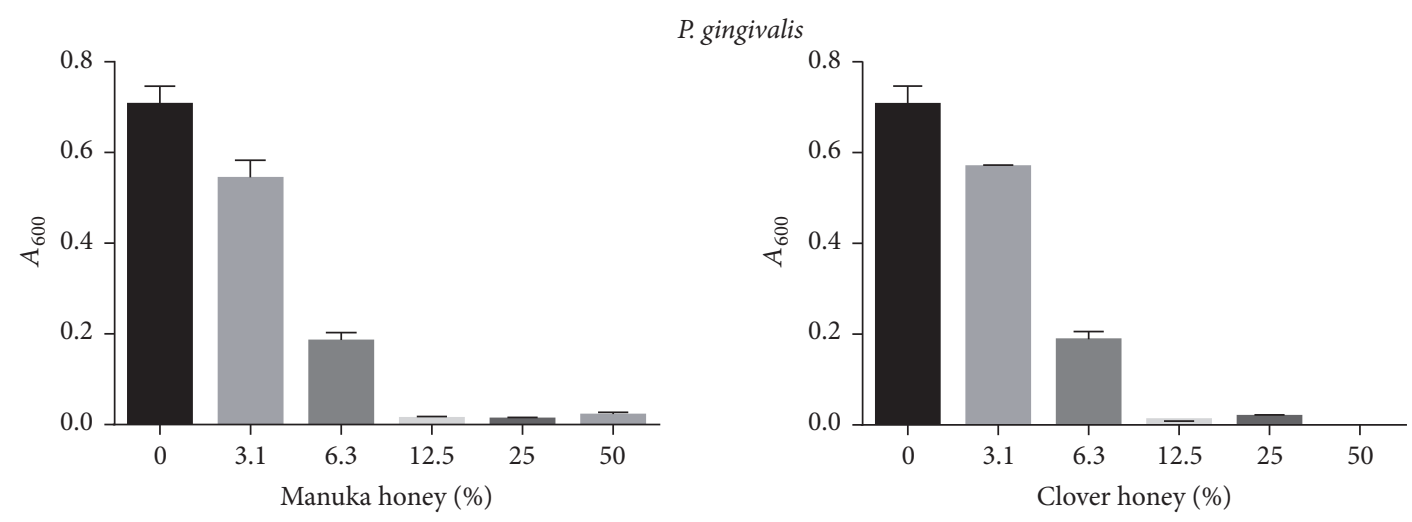

(e)

FIGURE 1: Minimum inhibitory concentrations (\% w/v) of manuka and white clover honeys against various bacteria after $18 \mathrm{~h}$ incubation. $\mathrm{pH}$ of honey dilutions is recorded (a). Bacterial growth was determined as culture density $\left(A_{600}\right)$ in a microtitre-plate reader. F. nucleatum: ATCC 25586.

TABLE 1: Minimum bactericidal concentrations (MBC) of manuka (NPA 20+) and white clover honeys against a variety of bacteria.

\begin{tabular}{|c|c|c|c|c|}
\hline \multirow{3}{*}{ Bacteria } & \multicolumn{4}{|c|}{$\mathrm{MBC}(\% \mathrm{w} / \mathrm{v})$} \\
\hline & \multicolumn{2}{|c|}{ Manuka honey NPA20+ } & \multicolumn{2}{|c|}{ White clover honey } \\
\hline & $\mathrm{pH} 4.9^{*}$ & $\mathrm{pH} 7.1$ & $\mathrm{pH} 5.2^{*}$ & $\mathrm{pH} 7.1$ \\
\hline Staph. aureus & 12.5 & 12.5 & 50 & $>50$ \\
\hline E. coli & 12.5 & 25 & 25 & 50 \\
\hline S. mutans UA159 & $>50$ & $>50$ & $>50$ & $>50$ \\
\hline S. mutans 10449 & 25 & 25 & 25 & 50 \\
\hline S. sobrinus & 12.5 & 12.5 & 25 & 25 \\
\hline S. sanguinis & 25 & 25 & 50 & 50 \\
\hline S. gordonii & 25 & 25 & 25 & $>50$ \\
\hline F. nucleatum ATCC 25586 & 12.5 & 12.5 & 25 & 25 \\
\hline F. nucleatum ATCC 33568 & 25 & 25 & 25 & 25 \\
\hline P. gingivalis & 12.5 & 12.5 & 12.5 & 25 \\
\hline P. intermedia & 12.5 & 12.5 & 25 & 12.5 \\
\hline
\end{tabular}

P. gingivalis and $P$. intermedia were incubated for $48 \mathrm{~h}$ while all other bacteria were incubated for $18 \mathrm{~h}$. The highest honey concentration tested was $50 \%$ (w/v). NPA: nonperoxide antibacterial activity.

${ }^{*}$ Natural $\mathrm{pH}$ at $50 \%(\mathrm{w} / \mathrm{v})$ in culture media.

pH-adjusted clover honey exhibited varying bactericidal activity (Table 1).

\subsection{Demineralisation of HA Beads Incubated in Honey.} Incubation of HA beads in dilute honey resulted in significant solubilisation of calcium as compared to incubation in water. The two types of honey did not differ significantly in this respect (Figure 3(a)). Demineralisation also occurred when honey/HA preparations were maintained at $4^{\circ} \mathrm{C}$ (Figure 3(a)), suggesting that the effect was due to low $\mathrm{pH}$ rather than biological activity.

When the assay was modified by the addition of $S$. mutans, both types of honey promoted significant demineralisation at lower concentrations (Figure 3(a)) and calcium solubilisation was positively correlated to $\left[\mathrm{H}^{+}\right](p<$ 0.01 ) (Figure 3(b)). Decalcification decreased as the honey concentrations increased, due to the antibacterial effects of the honey (Figure 3(a)).

\section{Discussion}

A few clinical studies have reported reduction in plaque accumulation and gingival bleeding $[26,30]$ and decreased proportion of mutans streptococci [31] with application of honey intraorally, supporting the use of honey as an oral antimicrobial agent. Thus, the present preclinical study assessed the potential for subgingival application of manuka honey in the treatment of periodontal diseases.

Both manuka and clover honeys were active against a variety of organisms including plaque-associated bacteria; manuka honey was more active in this respect. In agreement with other studies [24, 28, 32], P. gingivalis, P. intermedia, and 


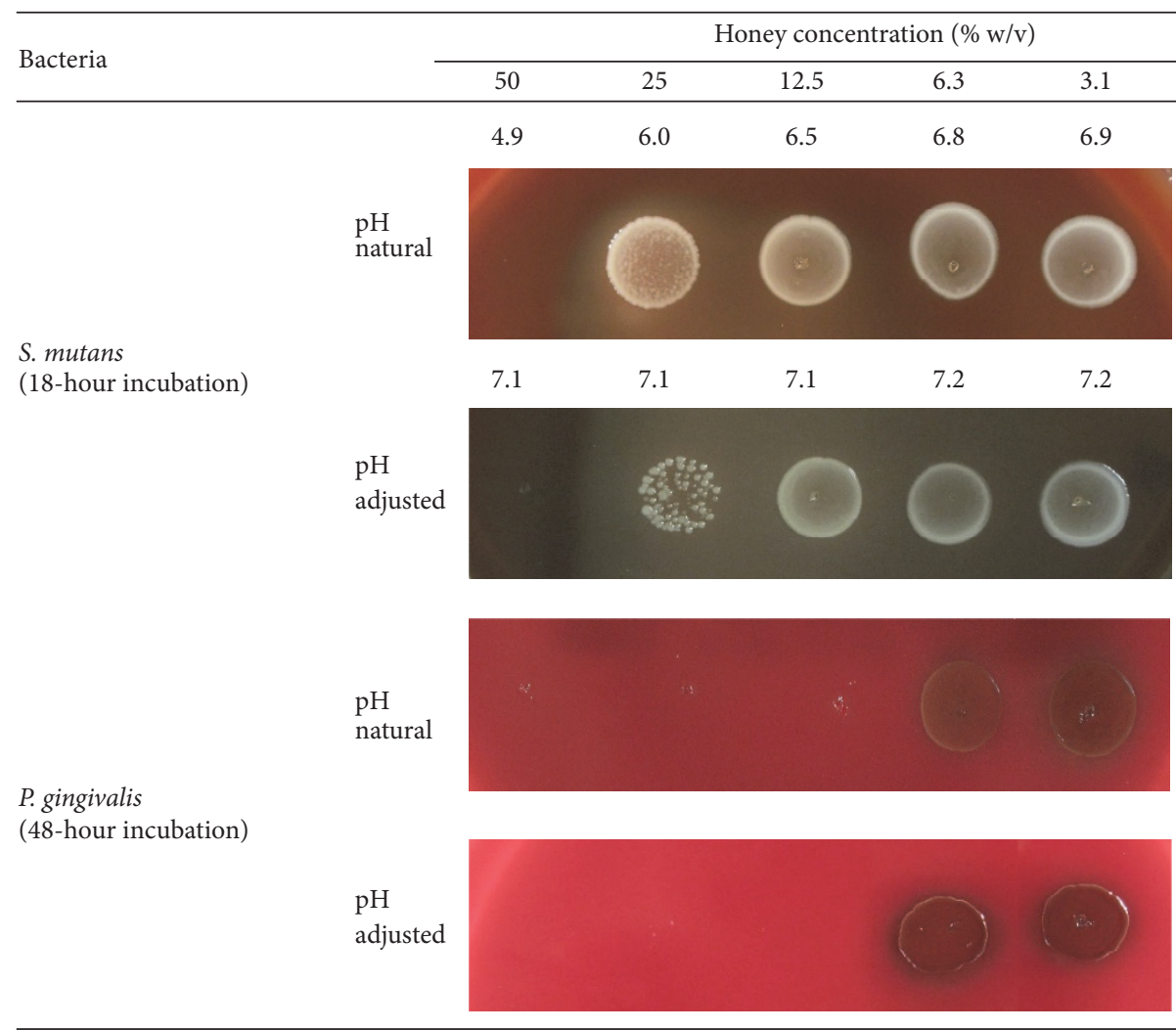

(a)

\begin{tabular}{llll}
\hline Incubation time & $1 \mathrm{~h}$ & $4 \mathrm{~h}$ & $18 \mathrm{~h}$ \\
\hline Bactericidal activity & & & \\
\hline
\end{tabular}

(b)

FIGURE 2: Bactericidal effect of manuka honey (NPA 25+) against (a) S. mutans and P. gingivalis and (b) effective incubation time of manuka honey $[50 \%(\mathrm{w} / \mathrm{v})]$ against $S$. mutans. NPA = nonperoxide antibacterial activity.

F. nucleatum, gram-negative bacteria associated with gingivitis and periodontal diseases, were more sensitive than the gram-positive species associated with gingival health (streptococci). Subgingival application of manuka honey could therefore conceivably promote health-associated species at the expense of those associated with periodontal diseases. However, S. mutans is generally considered cariogenic [33, 34] and was the most resistant of the tested organisms to both types of honey. As honey is principally composed of fermentable carbohydrates including fructose, glucose, and sucrose [35], localised application of manuka honey could conceivably select and encourage cariogenic species. Honey is considered cariogenic when consumed as a foodstuff [36].
As S. mutans is notably acid-tolerant $[37,38]$, the question arises as to whether the low $\mathrm{pH}$ of honey contributes to the antimicrobial effects against other species but adjusting the $\mathrm{pH}$ to neutrality had limited effect on the antimicrobial activity. The natural $\mathrm{pH}$ of honey ranges from 3.1 to 4.5 $[12,39]$, well below the accepted critical $\mathrm{pH}$ of 5.5 for enamel and more importantly cementum demineralisation $[40,41]$ further mitigating against subgingival application of honey to root surfaces as an adjunct in the treatment of periodontitis. On the other hand, the evidence for enamel demineralisation following prolonged in vitro exposure to honey is contradictory [42-44]. Dilute honey should pose less of a threat to mineralised tissues but would also have less antimicrobial activity. Our in vitro findings demonstrate 


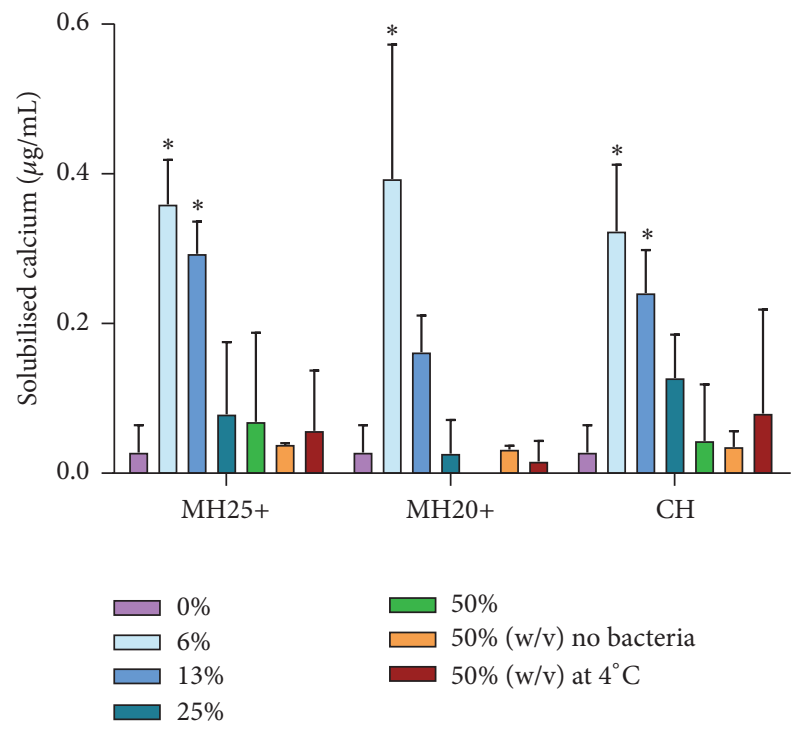

(a)

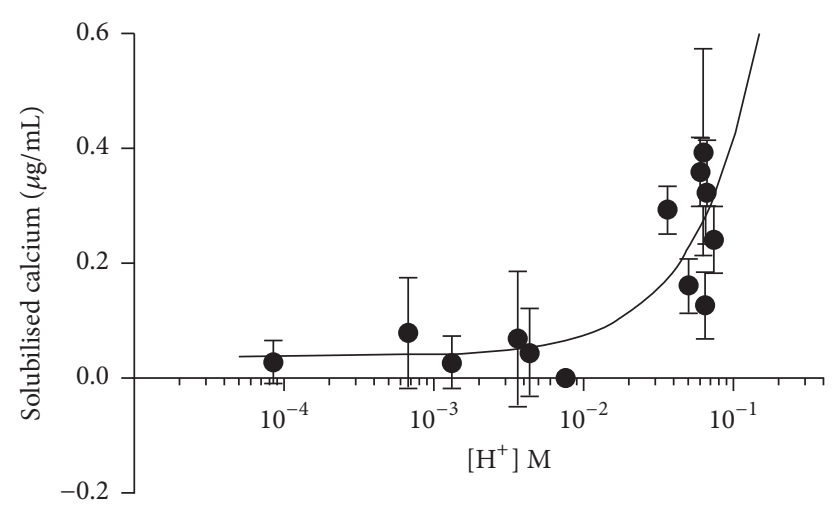

(b)

FIgURE 3: (a) Solubilisation of calcium from HA beads following incubation of $S$. mutans with manuka and clover honeys at $37^{\circ} \mathrm{C}$ and $4^{\circ} \mathrm{C}$. ${ }^{*}$ Significantly different from water control $(p<0.05$; oneway ANOVA with Dunnett's post hoc test). (b) Relationship between solubilised calcium and final proton concentration. Correlation between calcium solubilisation and $\left[\mathrm{H}^{+}\right]\left(r_{s}=0.770, p<0.01\right)$ Spearman's rho test. MH25+: manuka honey NPA25+; MH20+: manuka honey NPA 20+; CH: clover honey.

that diluting the honey not only reduces the antimicrobial activity but also promotes bacterial carbohydrate metabolism and consequent acid production by $S$. mutans, resulting in further demineralisation.

Pharmacokinetic studies of subgingivally delivered antimicrobial agents report exponential concentration reduction following application $[45,46]$, implying that the bacteriostatic action of honey will begin to diminish immediately following delivery to a periodontal pocket. Application of undiluted honey may have an effective initial antimicrobial effect but the low $\mathrm{pH}$ will facilitate demineralisation of adjacent cementum and, as the honey concentration falls, acid production by the surviving bacteria (i.e., fermentative streptococci) will promote further demineralisation.
Despite evidence that manuka honey provides effective antimicrobial effects when applied to soft tissues and encouraging clinical outcomes for intraoral use, our findings suggest that it could be damaging to calcified tissues. Nevertheless, whether a single application (rather than a sustained release) would deliver a beneficial antimicrobial effect without threatening root integrity remains to be determined. However, other beneficial oral applications of manuka honey, which do not threaten the mineralised tissues, might be considered, for example, to dental implants in the treatment of periimplantitis.

\section{Conclusion}

Medical-grade manuka honey (i.e., NPA > 20) is antimicrobial towards representative oral bacteria generally, and the gram-negative anaerobes associated with gingivitis are particularly sensitive. However, the relative resistance of cariogenic S. mutans in association with the high concentrations of fermentable carbohydrates in honey and the direct demineralisation of oral hard tissues caused by the low $\mathrm{pH}$ of honey mitigate against application as a subgingival sustainedrelease adjunct in the treatment of periodontal disease.

\section{Conflicts of Interest}

The authors declare that there are no conflicts of interest regarding the publication of this paper.

\section{Acknowledgments}

The authors are grateful to Dr. Helen English for her contribution. This study was supported by the New Zealand Dental Research Foundation, Lottery Health (New Zealand), the University of Malaya, and the Malaysian Ministry of Higher Education.

\section{References}

[1] L. Vandamme, A. Heyneman, H. Hoeksema, J. Verbelen, and S. Monstrey, "Honey in modern wound care: a systematic review," Burns, vol. 39, no. 8, pp. 1514-1525, 2013.

[2] Z. H. Israili, "Antimicrobial properties of honey," American Journal of Therapeutics, vol. 21, no. 4, pp. 304-323, 2014.

[3] M. Schneider, S. Coyle, M. Warnock, I. Gow, and L. Fyfe, "Antimicrobial activity and composition of manuka and portobello honey," Phytotherapy Research, vol. 27, no. 8, pp. 1162-1168, 2013.

[4] N. AL-Waili, A. Al Ghamdi, M. J. Ansari, Y. Al-Attal, A. AlMubarak, and K. Salom, "Differences in composition of honey samples and their impact on the antimicrobial activities against drug multiresistant bacteria and pathogenic fungi," Archives of Medical Research, vol. 44, no. 4, pp. 307-316, 2013.

[5] Y. Maeda, A. Loughrey, J. A. P. Earle et al., "Antibacterial activity of honey against community-associated methicillin-resistant Staphylococcus aureus (CA-MRSA)," Complementary Therapies in Clinical Practice, vol. 14, no. 2, pp. 77-82, 2008.

[6] P. C. Molan and J. A. Betts, "Clinical usage of honey as a wound dressing: an update," Journal of Wound Care, vol. 13, no. 9, pp. 353-356, 2004. 
[7] N. S. Al-Waili, K. Salom, and A. A. Al-Ghamdi, "Honey for wound healing, ulcers, and burns; data supporting its use in clinical practice," TheScientificWorldJournal, vol. 11, pp. 766-787, 2011.

[8] M. Charalambous, V. Raftopoulos, E. Lambrinou, and A. Charalambous, "The effectiveness of honey for the management of radiotherapy-induced oral mucositis in head and neck cancer patients: a systematic review of clinical trials," European Journal of Integrative Medicine, vol. 5, no. 3, pp. 217-225, 2013.

[9] A. B. Jull, N. Walker, and S. Deshpande, "Honey as a topical treatment for wounds," Cochrane Database of Systematic Reviews, vol. 2, Article ID CD005083, 2013.

[10] R. M. J. Rodrigues, C. Gonçalves, R. Souto, E. J. Feres-Filho, M. Uzeda, and A. P. V. Colombo, "Antibiotic resistance profile of the subgingival microbiota following systemic or local tetracycline therapy," Journal of Clinical Periodontology, vol. 31, no. 6, pp. 420-427, 2004.

[11] C. M. Ardila, M. I. Granada, and I. C. Guzmán, "Antibiotic resistance of subgingival species in chronic periodontitis patients," Journal of Periodontal Research, vol. 45, no. 4, pp. 557-563, 2010.

[12] J. Alvarez-Suarez, M. Gasparrini, T. Forbes-Hernández, L. Mazzoni, and F. Giampieri, "The composition and biological activity of honey: a focus on Manuka honey," Foods, vol. 3, no. 3, pp. 420-432, 2014.

[13] P. C. Molan, "The antibacterial activity of honey: 1. The nature of the antibacterial activity," Bee World, vol. 73, no. 1, pp. 5-28, 1992.

[14] K. L. Allen, P. C. Molan, and G. M. Reid, "A survey of the antibacterial activity of some New Zealand honeys," Journal of Pharmacy and Pharmacology, vol. 43, no. 12, pp. 817-822, 1991.

[15] E. Mavric, S. Wittmann, G. Barth, and T. Henle, "Identification and quantification of methylglyoxal as the dominant antibacterial constituent of Manuka (Leptospermum scoparium) honeys from New Zealand," Molecular Nutrition and Food Research, vol. 52, no. 4, pp. 483-489, 2008.

[16] C. J. Adams, C. H. Boult, B. J. Deadman et al., "Isolation by HPLC and characterisation of the bioactive fraction of New Zealand manuka (Leptospermum scoparium) honey," Carbohydrate Research, vol. 343, no. 4, pp. 651-659, 2008.

[17] J. M. Stephens, R. C. Schlothauer, B. D. Morris et al., "Phenolic compounds and methylglyoxal in some New Zealand manuka and kanuka honeys," Food Chemistry, vol. 120, no. 1, pp. 78-86, 2010.

[18] R. A. Cooper, P. C. Molan, and K. G. Harding, "The sensitivity to honey of Gram-positive cocci of clinical significance isolated from wounds," Journal of Applied Microbiology, vol. 93, no. 5, pp. 857-863, 2002.

[19] S. E. Maddocks, M. S. Lopez, R. S. Rowlands, and R. A. Cooper, "Manuka honey inhibits the development of Streptococcus pyogenes biofilms and causes reduced expression of two fibronectin binding proteins," Microbiology, vol. 158, no. 3, pp. 781-790, 2012.

[20] E. N. Hammond, E. S. Donkor, and C. A. Brown, "Biofilm formation of Clostridium difficile and susceptibility to Manuka Honey," BMC Complementary and Alternative Medicine, vol. 14, no. 1, article 329, 2014.

[21] A. D. Haffajee and S. S. Socransky, "Microbial etiological agents of destructive periodontal diseases," Periodontology 2000, vol. 5, no. 1, pp. 78-111, 1994.
[22] J. Slots, H. S. Reynolds, and R. J. Genco, "Actinobacillus actinomycetemcomitans in human periodontal disease: a crosssectional microbiological investigation," Infection and Immunity, vol. 29, no. 3, pp. 1013-1020, 1980.

[23] C. Badet and F. Quero, "The in vitro effect of manuka honeys on growth and adherence of oral bacteria," Anaerobe, vol. 17, no. 1, pp. 19-22, 2011.

[24] P. R. Schmidlin, H. English, W. Duncan, G. N. Belibasakis, and T. Thurnheer, "Antibacterial potential of Manuka honey against three oral bacteria in vitro," Swiss Dental Journal, vol. 124, no. 9, pp. 922-924, 2014.

[25] S. Eick, G. Schäfer, J. Kwieciński, J. Atrott, T. Henle, and W. Pfister, "Honey-a potential agent against Porphyromonas gingivalis: an in vitro study," BMC Oral Health, vol. 14 , no. 1, article 24, 2014.

[26] H. K. P. English, A. R. C. Pack, and P. C. Molan, "The effects of manuka honey on plaque and gingivitis: a pilot study," Journal of the International Academy of Periodontology, vol. 6, no. 2, pp. 63-67, 2004.

[27] R. A. Cooper, P. C. Molan, and K. G. Harding, "Antibacterial activity of honey against strains of Staphylococcus aureus from infected wounds," Journal of the Royal Society of Medicine, vol. 92, no. 6, pp. 283-285, 1999.

[28] P. H. S. Kwakman, A. A. te Velde, L. de Boer, C. M. J. E. Vandenbroucke-Grauls, and S. A. J. Zaat, "Two major medicinal honeys have different mechanisms of bactericidal activity," PLoS ONE, vol. 6, no. 3, Article ID el7709, 2011.

[29] Clinical and Laboratory Standard Institute, "Performance standards for antimicrobial disc susceptibility tests," Approved Standard M2-A9, 2012.

[30] S. Aparna, S. Srirangarajan, V. Malgi et al., "A comparative evaluation of the antibacterial efficacy of honey in vitro and antiplaque efficacy in a 4-day plaque regrowth model in vivo: preliminary results," Journal of Periodontology, vol. 83, no. 9, pp. 1116-1121, 2012.

[31] D. Steinberg, G. Kaine, and I. Gedalia, "Antibacterial effect of propolis and honey on oral bacteria," American Journal of Dentistry, vol. 9, no. 6, pp. 236-239, 1996.

[32] P. E. Lusby, A. L. Coombes, and J. M. Wilkinson, "Bactericidal activity of different honeys against pathogenic bacteria," Archives of Medical Research, vol. 36, no. 5, pp. 464-467, 2005.

[33] S. Hamada and H. D. Slade, "Biology, immunology, and cariogenicity of Streptococcus mutans," Microbiological Reviews, vol. 44, no. 2, pp. 331-384, 1980.

[34] W. J. Loesche, "Role of Streptococcus mutans in human dental decay," Microbiological Reviews, vol. 50, no. 4, pp. 353-380, 1986.

[35] R. J. Weston and L. K. Brocklebank, "The oligosaccharide composition of some New Zealand honeys," Food Chemistry, vol. 64, no. 1, pp. 33-37, 1999.

[36] W. H. Bowen and R. A. Lawrence, "Comparison of the cariogenicity of cola, honey, cow milk, human milk, and sucrose," Pediatrics, vol. 116, no. 4, pp. 921-926, 2005.

[37] W. A. Belli and R. E. Marquis, "Adaptation of Streptococcus mutans and Enterococcus hirae to acid stress in continuous culture," Applied and Environmental Microbiology, vol. 57, no. 4, pp. 1134-1138, 1991.

[38] I. R. Hamilton and N. D. Buckley, "Adaptation by Streptococcus mutans to acid tolerance," Oral Microbiology and Immunology, vol. 6, no. 2, pp. 65-71, 1991.

[39] J. W. White Jr., "Physical characteristics of honey," in Honey: A Comprehensive Survey, E. Crane, Ed., Heinemann, 1975. 
[40] R. P. Shellis, M. E. Barbour, S. B. Jones, and M. Addy, "Effects of $\mathrm{pH}$ and acid concentration on erosive dissolution of enamel, dentine, and compressed hydroxyapatite," European Journal of Oral Sciences, vol. 118, no. 5, pp. 475-482, 2010.

[41] P. M. M. Hoppenbrouwers, F. C. M. Driessens, and J. M. P. M. Borggreven, "The vulnerability of unexposed human dental roots to demineralization," Journal of Dental Research, vol. 65, no. 7, pp. 955-958, 1986.

[42] M. O. Sela, L. Shapira, I. Grizim et al., "Effects of honey consumption on enamel microhardness in normal versus xerostomic patients," Journal of Oral Rehabilitation, vol. 25, no. 8, pp. 630-634, 1998.

[43] S. R. Grobler, I. J. Du Toit, and N. J. Basson, "The effect of honey on human tooth enamel in vitro observed by electron microscopy and microhardness measurements," Archives of Oral Biology, vol. 39, no. 2, pp. 147-153, 1994.

[44] F. Ahmadi-Motamayel, L. Rezaei-Soufi, L. Kiani, M. Y. Alikhani, J. Poorolajal, and M. Moghadam, "Effects of honey, glucose, and fructose on the enamel demineralization depth," Journal of Dental Sciences, vol. 8, no. 2, pp. 147-150, 2013.

[45] J. M. Goodson, D. Holborow, R. L. Dunn, P. Hogan, and S. Dunham, "Monolithic tetracycline-containing fibers for controlled delivery to periodontal pockets," Journal of Periodontology, vol. 54, no. 10, pp. 575-579, 1983.

[46] A. M. Straub, J. Suvan, N. P. Lang et al., "Phase 1 evaluation of a local delivery device releasing silver ions in periodontal pockets: safety, pharmacokinetics and bioavailability," Journal of Periodontal Research, vol. 36, no. 3, pp. 187-193, 2001. 


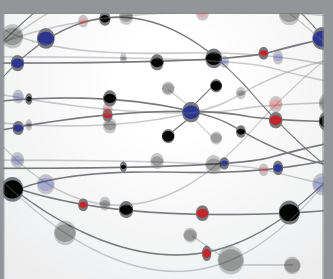

The Scientific World Journal
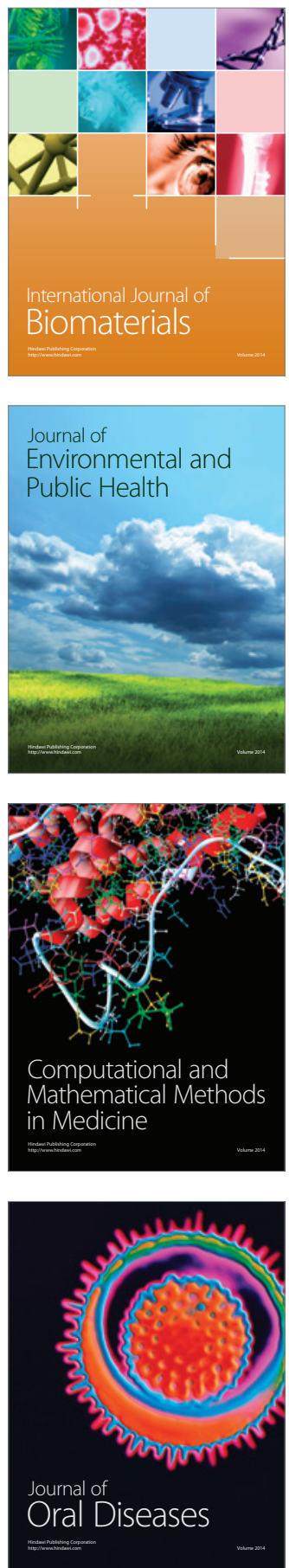
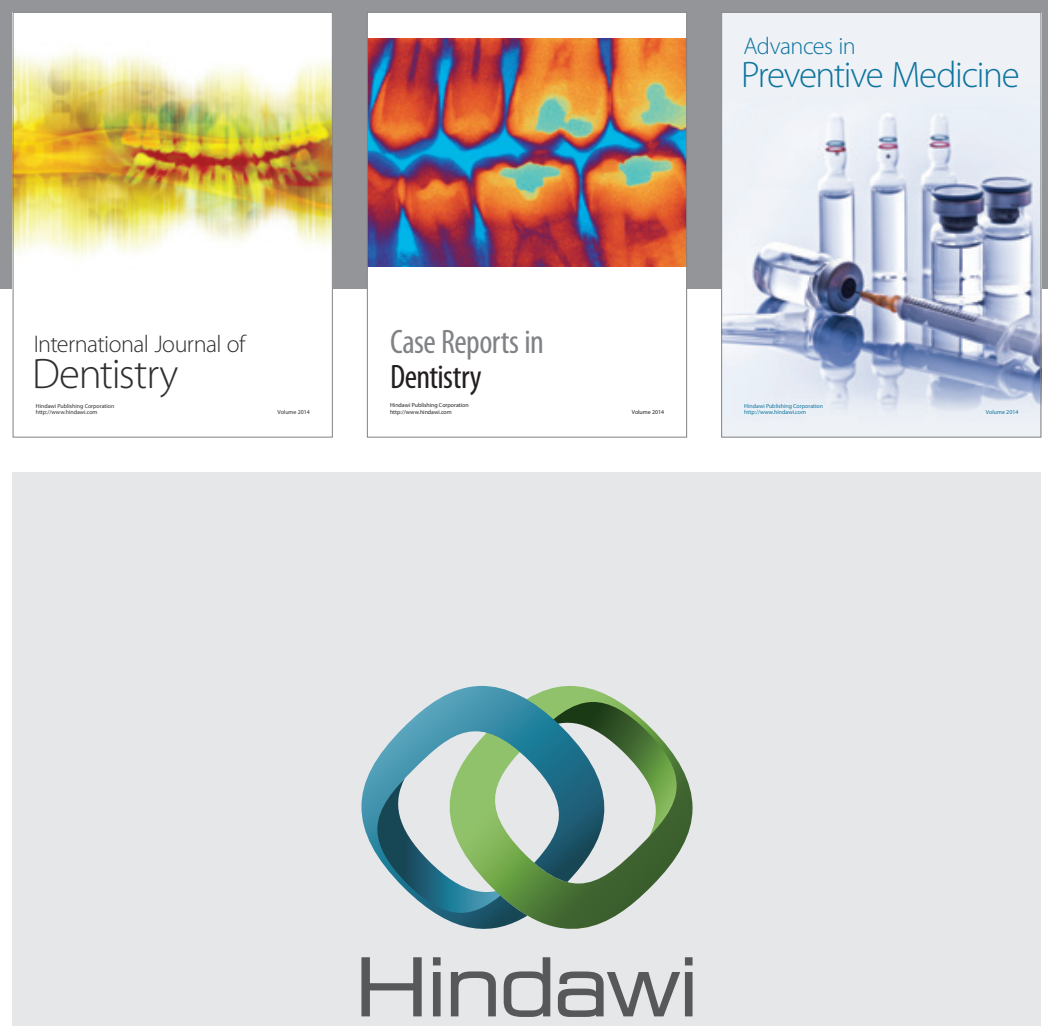

Submit your manuscripts at

https://www.hindawi.com
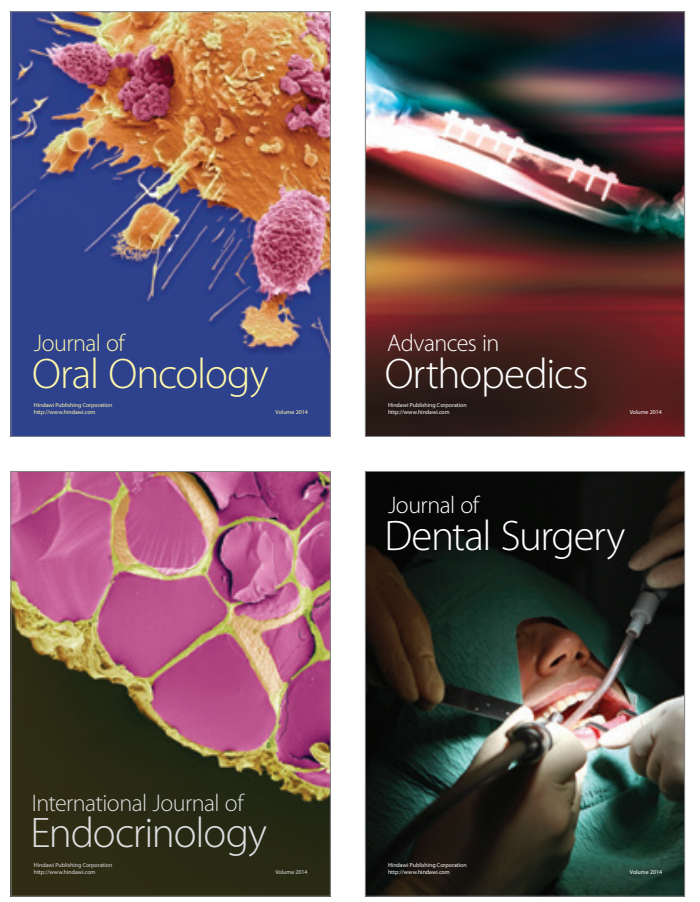
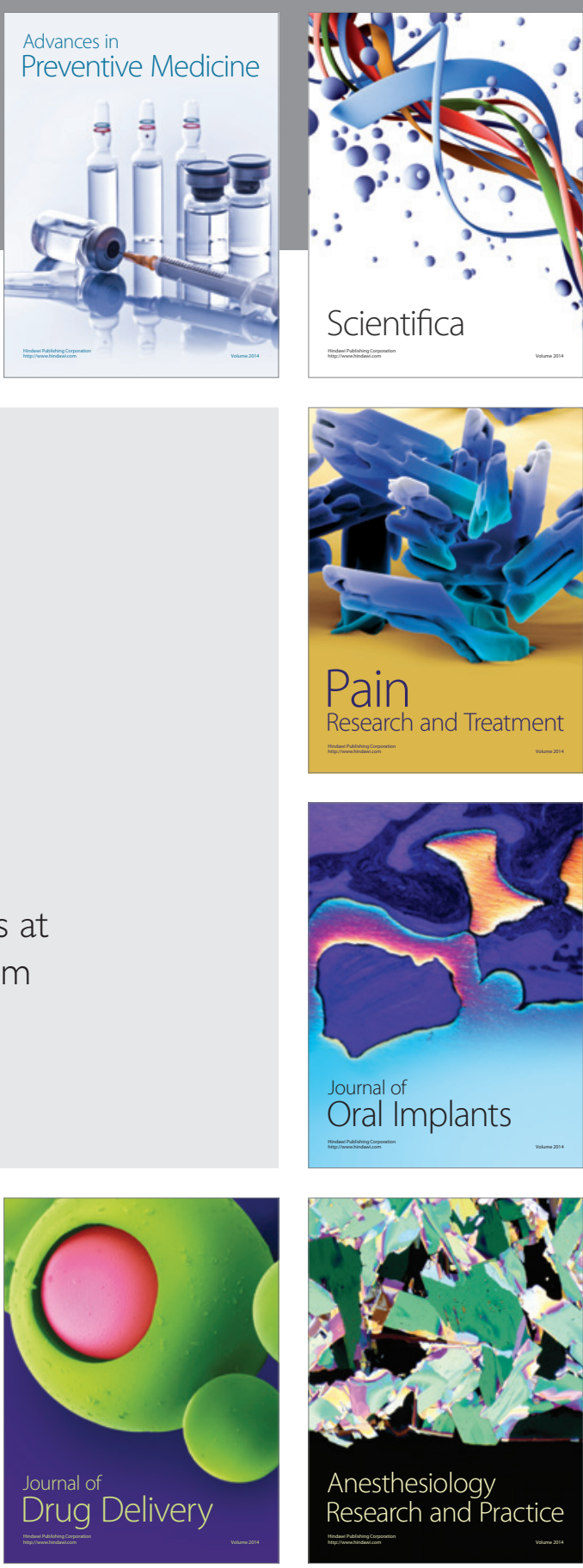

Scientifica
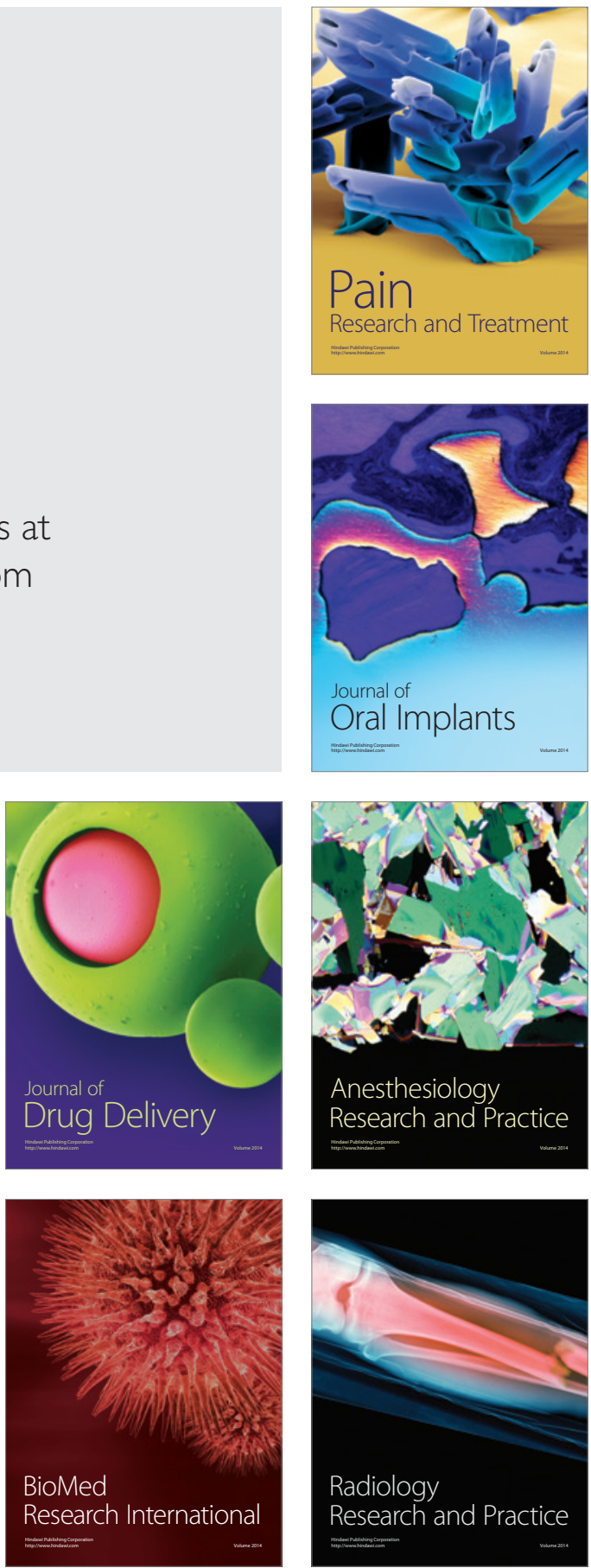